The BMJ

Cite this as: BMJ 2022;376:038 http://dx.doi.org/10.1136/bmj.038 Published: 07 January 2022

\section{Covid-19: Shorten isolation periods to relieve NHS pressures, say leaders}

\section{Elisabeth Mahase}

Redeploying medical students and trainees is one of the steps that are needed immediately to relieve pressure on the NHS as hospitals struggle to deal with staff absences, the organisation that represents trusts has said.

The NHS Confederation has also called for the self-isolation period for people infected with covid-19 to be shortened to five days, in line with the US and France, if the evidence shows this poses no risk to patients. In a statement calling for urgent action, it argued that this would "significantly help to reduce the level of staff absence over the rest of the winter."

It also said that clinical leaders and regulators must recognise the "exceptional circumstances" staff are working in, including the "explicit acknowledgment" that clinical tasks may need to be allocated in ways which would not normally be recognised as best practice.

\section{Staff absences}

Several trusts have declared critical incidents because of staff absences, with many staff off because of sickness or self-isolation requirements. ${ }^{1}$ Some hospitals are reporting that around $10 \%$ of their staff are currently absent. ${ }^{2}$ This comes as nearly 1.3 million new covid-19 cases were reported in the past week in the UK (31 December to 6 January 2022)-where omicron is the dominant variant. ${ }^{3}$

Helen Buckingham, director of the Nuffield Trust, said, "NHS hospitals are experiencing severe levels of staff absences and patients are already seeing an impact on services. On average over 80,000 staff were absent every day in the week ending 2 January-equivalent to around 1 in 12 of those employed in these services."

NHS Confederation chief executive Matthew Taylor added, "The government now needs to do all it can to mobilise more staff and other resources for the NHS to get through this extremely challenging period. We should not be in this position two years into the pandemic.”

\section{Deploying students}

One suggestion to relieve some immediate pressure is to bring in medical students to provide additional support on the wards or administratively, as was done during the first wave in March 2020. ${ }^{4}$

Kiran Patel, chief medical officer at University Hospital Coventry and Warwickshire who helped organise medical student volunteers during the first wave, told The BMJ that his trust is not yet using medical students in this way as education is still being delivered and it is crucial that this is not impacted. However, he has started asking students if they might want to volunteer for support work, to go alongside their normal studies.

\section{Flexible infection control measures}

Patel said another area to look at is infection prevention and control (IPC). "One thing we could do is review IPC measures,” he said. "Our IPC measures need to be agile to make sure that they don't invoke pressure in the system. But, at the other end of the spectrum, they need to be safe enough to safeguard patients." One possible change could be reducing the 14 day isolation period for inpatients who are known to have been exposed to a confirmed covid-19 case while in hospital, he said. ${ }^{5}$

Discharging patients into care homes and other care settings is another factor that NHS Confederation said is contributing to the pressure. It said hospitals are struggling to move patients out of hospital, often because of lack of capacity, staff absence in social care, and some patients choosing not to leave hospital until they have a social care provider of their choice.

To aid this, NHS Confederation is calling on the government to publish guidance enabling patients to be transferred to a suitable placement from where they can then choose a provider. "The risk otherwise is that more hospital beds will be taken up by patients who are clinically ready to be discharged into the community but unable to be transferred," it said.

\section{Advice to seek care}

NHS Confederation also wants the government to provide the public with "clear and consistent" advice on what they should do when they experience minor illness to "avoid GPs and emergency departments being overwhelmed."

There are concerns, however, that the NHS could see a repeat from earlier waves where people who needed healthcare did not come forward because of fears of getting the virus and messaging about protecting the NHS. Leaders have previously warned that this led to patients' health worsening and contributed to the care backlog the NHS is now struggling to tackle. ${ }^{6}$

Patel said, "It's a time of anxiety, but we need to reassure patients and the population that we will deliver the urgent and acute care that they need. What we don't want is patients not coming to hospital when they need care, and that's what we saw during the first and second wave of covid-19-people would stay at home in order to 'protect the NHS.' Actually, I would change the mantra and say the NHS is here to protect you, so use it appropriately, and we will deliver the care that you need." 
2 Two more NHS trusts declare critical incidents over staff covid absences. Guardian. 4 January 2022. www.theguardian.com/society/2022/jan/04/two-more-nhs-trusts-declare-critical-incidentsover-staff-covid-absences.

3 Coronavirus in the UK. https://coronavirus.data.gov.uk.

4 Mahase E. Covid-19: medical students to be employed by NHS as part of epidemic response. BM/2020;368:m1156. doi: 10.1136/bmj.m1156 pmid: 32198184

5 Covid-19: management of staff and exposed patients or residents in health and social care settings. 30 December 2021. www.gov.uk/government/publications/covid-19-management-ofexposed-healthcare-workers-and-patients-in-hospital-settings/covid-19-management-of-exposedhealthcare-workers-and-patients-in-hospital-settings.

6 Mahase E. Winter will be "exceptionally difficult" for NHS irrespective of covid, Chris Whitty warns. BMI2021;375:n2534. doi: 10.1136/bmj.n2534 pmid: 34663567

This article is made freely available for personal use in accordance with BMJ's website terms and conditions for the duration of the covid-19 pandemic or until otherwise determined by BMJ. You may download and print the article for any lawful, non-commercial purpose (including text and data mining) provided that all copyright notices and trade marks are retained. 